\title{
Regulation of microRNA-497 expression in human cancer (Review)
}

\author{
GUANSHUI LUO ${ }^{1,2}$, KE HE $^{1}$, ZHENGLIN XIA $^{1}$, SHUAI LIU $^{1}$, HONG LIU $^{1}$ and GUOAN XIANG ${ }^{1}$ \\ ${ }^{1}$ Department of General Surgery, Guangdong Second Provincial General Hospital, Guangzhou, \\ Guangdong 510317; ${ }^{2}$ Department of Postgraduate Studies, The Second Clinical College of \\ Southern Medical University, Guangzhou, Guangdong 510515, P.R. China
}

Received March 19, 2020; Accepted August 28, 2020

DOI: $10.3892 / 01.2020 .12284$

\begin{abstract}
MicroRNAs (miRNAs/miRs) are a type of non-coding single-stranded RNA, with a length of $22 \mathrm{nt}$, which are encoded by endogenous genes and are involved in the post-transcriptional regulation of gene expression in animals and plants. Studies have demonstrated that miRNAs play an important role in the occurrence, development, metastasis, diagnosis and treatment of cancer. In recent years, miR-497 has been identified as one of the key miRNAs in a variety of cancer types and has been shown to be downregulated in a variety of solid tumors. However, the regulation of miR-497 expression involves a complex network, which is affected by several factors. The aim of the present review was to summarize the mechanism of regulation of miR-497 expression at the pre-transcriptional and transcriptional levels in cancer, as well as the role of miR-497 expression imbalance in cancer diagnosis, treatment and prognosis. The regulatory mechanisms of miR-497 expression may aid in our understanding of the causes of miR-497 expression imbalance and provide a reference value for further research on the diagnosis and treatment of cancer.
\end{abstract}

\section{Contents}

1. Introduction

2. miR-497 biogenesis

3. Regulation of miR-497 expression

4. Clinical significance of miR-497

5. Conclusions and prospects

Correspondence to: Professor Guoan Xiang, Department of General Surgery, Guangdong Second Provincial General Hospital, 466 Xingang Middle Road, Guangzhou, Guangdong 510317, P.R. China

E-mail: guoan_66@163.com

Key words: microRNA-497, expression, cancer, regulatory mechanisms, clinical significance

\section{Introduction}

According to recent global cancer statistics, there were an estimated 18.1 million new cancer cases and 9.6 million cancer-associated deaths in 2018 (1). Accumulating evidence indicates that miRNAs (miRNAs/miRs) may act as oncogenes or tumor suppressor, and play critical roles in the occurrence and development of cancer (2). miRNAs are a class of non-coding RNA (ncRNA) with a length of 22 nt. In 1993, Lee et al (3) first discovered miRNAs in Caenorhabditis elegans, which prompted intense research on miRNAs. RNA interference technology (4), which was subsequently discovered in 1998, markedly advanced the research on miRNAs. To date, thousands of miRNAs have been reported in vertebrates, with 2,654 in humans (5). Dysregulation of miRNA expression has become a hallmark of various cancer types (6). Among the miRNAs that are known to be abnormally expressed, miR-497 is considered to be one of the miRNAs that play a key role in the pathogenesis of cancer (7).

miR-497 is encoded by the first intron of the MIR497HG gene located on human chromosome 17p13.1 (8). miR497 belongs to the miR-15/16/195/424/497 family that have the same 3'-untranslated (UTR) binding seed sequence (AGCAGCA) (9). During autopsy, it was found that the expression of miR-497 was similar in various normal tissues, including the cerebral cortex, frontal cortex, primary visual cortex, thalamus, heart, lungs, liver, kidneys, spleen, stomach and skeletal muscle (10). However, an imbalance in miR-497 expression is closely associated with the occurrence and development of tumors. Based on a study of the global miRNA expression profile of primary breast cancer, miR-497 was the first miRNA that was confirmed to be downregulated in breast cancer (11). Subsequently, a study of the global miRNA expression profile of gastric cancer was the first to demonstrate that the expression of miR-497 was increased in non-tumor tissues (12). Accumulating evidence shows that the expression of miR-497 is downregulated in several tumor types, including primary peritoneal carcinoma (13), adrenocortical carcinoma $(14,15)$, malignant astrocytoma (16), colorectal cancer (17-21), osteosarcoma (22), cervical cancer (23), liver cancer (24-28), breast cancer (29-31), neuroblastoma (32), non-small cell lung cancer (33-35), gastric cancer (36-38), ovarian cancer (39), nasopharyngeal carcinoma (40), osteosarcoma $(41,42)$, angiosarcoma (43), cervical 
cancer $(44,45)$, thyroid cancer $(46,47)$, cutaneous squamous cell carcinoma $(48,49)$, melanoma (50), glioma (51), clear cell renal cell carcinoma (52), anaplastic large cell lymphoma (53), esophageal carcinoma (54) and bladder cancer (9), among others. These results suggest that miR-497 acts as a tumor suppressor. Notably, the expression of miR-497 has been found to be upregulated in hepatocellular carcinoma (55), chronic lymphoblastic leukemia (56), and head and neck squamous cell carcinoma (57). This finding suggests that miR-497 may play different roles in different types of tumors. To comprehensively summarize the regulation of miR-497 expression in cancer, a total of 285 studies associated with the analysis of miR-497 have been compiled. The aim of the present review was to focus on the mechanism of regulation of miR-497 expression at the pre-transcriptional and transcriptional levels in cancer, and to emphasize the role of miR-497 in chemotherapeutic drug resistance and the diagnosis and treatment of malignant tumors. The specific expression, targets and functions of miR-497 in different cancer types are shown in Table I.

\section{2. miR-497 biogenesis}

The biosynthesis of miR-497 is mediated by multiple steps: i) The MIR497HG gene (NCBI gene ID, 574456) on chromosome 17 produces a long primary miRNA (pri-miRNA) transcript (pri-miR-497) through RNA polymerase II transcription; ii) pri-miRNA is processed by the Drosha complex in the nucleus into RNA with a hairpin structure, which is termed precursor miRNA (pre-miRNA)-497; iii) pre-miR-497 is transported into the cytoplasm by GTP-binding nuclear protein Ran and exportin-5; iv) pre-miR-497 is cleaved by Dicer to produce double strands with a length of $22 \mathrm{nt}$ : miR-497, miRNA*. miRNA*, known as the passenger strand, is discarded; v) the double-stranded body is directed into the argonaute (Ago)2 protein to form a RNA-induced silencing complex (RISC); vi) of the two miRNA double strands, only one chain (miR-497, guide chain) is retained in the Ago protein and stably forms RISC, whereas the other chain is discarded as a passing chain (miR-497*); and vii) the Ago-miRNA complex mainly binds to the 3'UTR of the target mRNA in a sequence-specific manner. miRNA target recognition usually depends on the seed sequence of the miRNA, so one miRNA can target and regulate multiple mRNAs (58).

\section{Regulation of miR-497 expression}

Genetics. Copy number abnormalities are a type of genomic structural variation, and they may be divided into two levels according to size, namely the microscopic and submicroscopic levels. Genomic structural variation at the submicroscopic level refers to variations in the length of DNA fragments of $1 \mathrm{~Kb}$ to $3 \mathrm{Mb}$, including deletion, insertion, repetition, rearrangement, inversion and changes in the number of DNA copies, among others. It has been reported that there is a high frequency of loss of heterozygosity on chromosome 17p13.1 (miR497 genomic locus), and the downregulation of miR-497 may be associated with the unique allele loss pattern in primary peritoneal carcinoma (13). It has also been reported that $\sim 71 \%$ of colon cancer tissues display a decrease in DNA copy number $(78,000-1,000,000)$ in a certain segment of chromosome 17p13.1, and the expression level of miR-497 was shown to be significantly decreased in colon cancer tissue samples, indicating that the downregulation of miR-497 in colon cancer is closely associated with the decrease in DNA copy number (17). Deletions and duplications of chromosomal loci may reduce or increase the copy number of miRNAs, which may have a significant impact on explaining the genetic heterogeneity of cancer.

\section{Epigenetics}

Regulation of DNA methylation. Studies have demonstrated that DNA methylation can control gene expression, and more specifically, that promoter DNA hypermethylation can downregulate gene expression $(59,60)$. It has been observed that the $\mathrm{CpG}$ island located upstream of the pri-miR-497 transcription initiation site is methylated by monoallelic methylation in the normal colonic mucosa, while in $\sim 75 \%$ of colorectal adenomas, the island is hypermethylated, and this change is associated with a significant downregulation of miR-497 expression (8). Another study demonstrated that miR-497 DNA is highly methylated and miR-497 expression is downregulated in hepatocellular carcinoma (HCC). Bioinformatics analysis revealed that the expression of the miR-195/497 cluster may be affected not only by its hypermethylated promoter region, but also by hypermethylated transcription factors (TFs) neurogenin 2 and DNA damage inducible transcript 3 (25). These results suggest that DNA methylation can regulate the transcriptional activity of miR-497, resulting in the downregulation of miR-497 expression in cancer.

Mutual regulation of miR-497 and long non-coding RNA (lncRNA). The term lncRNA refers to an ncRNA that is $>200 \mathrm{nt}$ in length. lncRNAs may act as endogenous target simulators, regulating gene expression by competing with miRNAs; this mode of action is referred to as the 'miRNA sponge' method, and IncRNAs with this function are known as competitive endogenous RNAs (ceRNAs). This mode is a relatively simple regulatory mechanism in the function of lncRNAs (61).

The lncRNA X-inactive specific transcript (XIST) is one of the earliest lncRNAs identified in mammals and plays an important role in X chromosome inactivation (62). The imbalance of XIST expression may play the role of an oncogene or tumor suppressor gene in different malignant tumors (63). In gastric cancer, the expression of XIST is upregulated and can be inhibited with miR-497. Further study revealed that XIST promotes the proliferation and metastasis of gastric cancer cells by regulating the miR497/metastasis-associated in colon cancer-1 axis (64). It has also been reported that XIST may act as an miR-497 'sponge', which targets programmed cell death protein 4 to further regulate the proliferation and migration of HCC cells (55).

There is a close functional association between the lncRNA plasmacytoma variant translocation 1 (PVT1) and Myc, which plays a carcinogenic role in a variety of cancer types (65). It was previously demonstrated that the expression of PVT1 is specifically increased in osteosarcoma cells and tissues, and acts as a molecular sponge to inhibit the expression of miR-497, indicating that PVT1 promotes glucose metabolism, cell proliferation and the metastasis of osteosarcoma cells 
Table I. Expression, targets, biological functions and role of miRNA-497 in cancer.

\begin{tabular}{|c|c|c|c|c|c|}
\hline Cancer type & Expression & Targets & Biological functions & Roles & (Refs.) \\
\hline $\begin{array}{l}\text { Primary peritoneal } \\
\text { carcinoma }\end{array}$ & Downregulated & Unknown & Unknown & $\begin{array}{l}\text { Tumor } \\
\text { suppressor }\end{array}$ & (13) \\
\hline Breast cancer & Downregulated & $\begin{array}{l}\text { BCL2L2, RAF1, } \\
\text { CCND1 BCL2, } \\
\text { ESRRA }\end{array}$ & $\begin{array}{l}\text { Induces apoptosis, } \\
\text { suppresses cell proliferation } \\
\text { and invasion }\end{array}$ & $\begin{array}{l}\text { Tumor } \\
\text { suppressor }\end{array}$ & $\begin{array}{c}(29-31 \\
125)\end{array}$ \\
\hline Colorectal cancer & Downregulated & $\begin{array}{l}\text { IGF1-R, KSR1, } \\
\text { FOSL1, IRS1, PTPN3 }\end{array}$ & $\begin{array}{l}\text { Inhibits cell survival, } \\
\text { proliferation and invasion, } \\
\text { and inhibits tumor growth }\end{array}$ & $\begin{array}{l}\text { Tumor } \\
\text { suppressor }\end{array}$ & $(17-21)$ \\
\hline \multirow[t]{2}{*}{$\begin{array}{l}\text { Hepatocellular } \\
\text { carcinoma }\end{array}$} & Downregulated & $\begin{array}{l}\text { CCNE1, CDC } 25 \mathrm{~A}, \\
\text { CCND3, CDK } 4, \\
\text { BTRC, CHEK } 1, \\
\text { VEGFA, SSRP1 }\end{array}$ & $\begin{array}{l}\text { Regulates cell cycle } \\
\text { progression, and suppresses } \\
\text { cell pro-angiogenic and } \\
\text { metastatic abilities }\end{array}$ & $\begin{array}{l}\text { Tumor } \\
\text { suppressor }\end{array}$ & $\begin{array}{c}(24, \\
26-28)\end{array}$ \\
\hline & Upregulated & PDCD4 & $\begin{array}{l}\text { Increases tumor size and } \\
\text { tumor number }\end{array}$ & Tumor promoter & $(55)$ \\
\hline Neuroblastoma & Downregulated & WEE1 & Increases apoptosis & Tumor suppressor & $(32)$ \\
\hline $\begin{array}{l}\text { Non-small cell lung } \\
\text { cancer }\end{array}$ & Downregulated & $\begin{array}{l}\text { HDGF, MTDH, } \\
\text { FGF2 }\end{array}$ & $\begin{array}{l}\text { Inhibits cell proliferation } \\
\text { and colony formation, and } \\
\text { suppresses EMT }\end{array}$ & Tumor suppressor & $(33-35)$ \\
\hline $\begin{array}{l}\text { Adrenocortical } \\
\text { carcinoma }\end{array}$ & Downregulated & TARBP2, DICER & Increases cell apoptosis & Tumor suppressor & $(15)$ \\
\hline Gastric cancer & Downregulated & eIF4E, FGFR1, PDK3 & Inhibits cell proliferation & Tumor suppressor & $(36-38)$ \\
\hline Ovarian cancer & Downregulated & SMURF1 & $\begin{array}{l}\text { Suppresses cell migration } \\
\text { and invasion }\end{array}$ & Tumor suppressor & (39) \\
\hline Prostate cancer & Downregulated & IKBKB & $\begin{array}{l}\text { Inhibits cell proliferation, } \\
\text { migration and invasion }\end{array}$ & Tumor suppressor & $(103)$ \\
\hline $\begin{array}{l}\text { Nasopharyngeal } \\
\text { carcinoma }\end{array}$ & Downregulated & ANLN, HSPA4L & Inhibits tumor growth & Tumor suppressor & $(40)$ \\
\hline Osteosarcoma & Downregulated & AMOT, ARL2 & $\begin{array}{l}\text { Suppresses cell proliferation } \\
\text { and invasion }\end{array}$ & Tumor suppressor & $(41,42)$ \\
\hline Angiosarcoma & Downregulated & KCNN4 & $\begin{array}{l}\text { Inhibits cell proliferation } \\
\text { and invasion }\end{array}$ & Tumor suppressor & $(43)$ \\
\hline Cervical cancer & Downregulated & TKT, CBX4 & Regulates chemosensitivity & Tumor suppressor & $(44,45)$ \\
\hline Thyroid cancer & Downregulated & BDNF, AKT3 & $\begin{array}{l}\text { Inhibits tumor cell } \\
\text { proliferation and invasion }\end{array}$ & Tumor suppressor & $(46,47)$ \\
\hline $\begin{array}{l}\text { Cutaneous squamous } \\
\text { cell carcinoma }\end{array}$ & Downregulated & $\begin{array}{l}\text { SERPINE-1, } \\
\text { FAM114A2 }\end{array}$ & Induces reversion of EMT & Tumor suppressor & $(48,49)$ \\
\hline Melanoma & Downregulated & TERT & $\begin{array}{l}\text { Inhibits cell proliferation, } \\
\text { migration and invasion }\end{array}$ & Tumor suppressor & $(50)$ \\
\hline Glioma & Downregulated & WNT3A & $\begin{array}{l}\text { Decreases cell growth and } \\
\text { invasion }\end{array}$ & Tumor suppressor & $(51)$ \\
\hline $\begin{array}{l}\text { Clear cell renal } \\
\text { cell carcinoma }\end{array}$ & Downregulated & CD274 & $\begin{array}{l}\text { Inhibits cell proliferation, } \\
\text { clone formation and migration }\end{array}$ & Tumor suppressor & $(52)$ \\
\hline $\begin{array}{l}\text { Anaplastic large } \\
\text { cell lymphoma }\end{array}$ & Downregulated & CDK6 & Inhibits cell proliferation & Tumor suppressor & $(53)$ \\
\hline Esophageal carcinoma & Downregulated & PELP1 & Unknown & Unknown & $(54,87)$ \\
\hline $\begin{array}{l}\text { Chronic } \\
\text { lymphoblastic leukemia }\end{array}$ & Upregulated & BCL2 & Unknown & Tumor promoter & $(56)$ \\
\hline $\begin{array}{l}\text { Squamous cell } \\
\text { carcinoma of the head } \\
\text { and neck }\end{array}$ & Upregulated & Unknown & Unknown & Tumor promoter & (57) \\
\hline
\end{tabular}

EMT, epithelial to mesenchymal transition. 
through the miR497/ hexokinase 2 pathway (66). It was also demonstrated that the expression of PVT1 is upregulated in non-small cell lung cancer (NSCLC) tissues, and that it inhibits cancer cell viability and induces apoptosis through negative regulation of miR-497. Further in vivo experiments revealed that PVT1 gene knockout may inhibit tumor growth and promote miR-497 expression in vivo (67).

The lncRNA gastric cancer-associated transcript 3 (GACAT3) is located on human Chr2p24.3 and its expression has been reported to be significantly associated with gastric cancer progression. Some experiments have proven that GACAT3 directly binds to miR-497 and negatively regulates the expression of miR-497 to promote the progression of gastric cancer (68). Other experiments demonstrated that GACAT3 acts as the ceRNA of miR-497, enhancing the expression of Cyclin D2, which in turn promotes the development of breast cancer (69).

The lncRNA nuclear paraspeckle assembly transcript1 (NEAT1) is a type of ncRNA, with a length of $3.2 \mathrm{~kb}$, which is mainly enriched in the nucleus. In gastric cancer, NEAT1 acts as an oncogene and can promote the growth of gastric cancer cells by regulating the miR-497/phosphoinositide-3-kinase regulatory subunit 1 axis (70).

The IncRNA LINC00152, which is located in human Chr2p11.2, is reported to be upregulated in several types of cancer. In thyroid cancer, LINC00152 acts as a miR-497 'sponge', downregulating its downstream target, brain-derived neurotrophic factor (BDNF), to promote the proliferation and invasion of papillary thyroid cancer cells (71). In multiple myeloma, LINC00152 acts as an oncogene and regulates cell growth by targeting miR-497 expression (72).

The lncRNA LINC00662 is located on chromosomal band $19 \mathrm{q} 11$ and its length is $2,085 \mathrm{bp}$. It was reported that the expression of LINC00662 is increased in lung cancer, nasopharyngeal carcinoma, oral squamous cell carcinoma and other malignant tumors (73). LINC00662 has also been reported to play a carcinogenic role in gastric cancer through the LINC00662-miR-497-Hippo-yes-associated protein 1 (YAP1) axis (74).

The IncRNA LINC00978 is located in the 2 q13 region of the human chromosome. It was recently reported that the expression of LINC00978 is upregulated in lung, breast and gastric cancer, as well as other malignant tumors, and is associated with a poor prognosis (75). It was demonstrated that LINC00978 inhibits the expression of miR-497 by acting as a ceRNA, and that it targets and suppresses the expression of neurotrophic receptor tyrosine kinase 3 and promotes the proliferation of gastric cancer cells (76).

The lncRNA small nucleolar RNA host gene 1 (SNHG1) is located in 11q12.3 and is widely expressed in cancer tissues. Recently, new evidence from basic and clinical studies has suggested that SNHG1 is involved in tumorigenesis and is an indicator of a poor prognosis in different types of cancer, such as hepatocellular carcinoma, gastric cancer and epithelial ovarian cancer (77). A previous study has found that SNHG1 acts as a miR-497 'sponge' to regulate the expression of insulin-like growth factor receptor (IGF1-R), and then promotes the proliferation and invasion of NSCLC (78). Other study has reported that SNHG1 and miR-497/miR-195-5p synergistically regulate the epithelial-to-mesenchymal transition (EMT) of colorectal cells (79).
The lncRNA small nucleolar RNA host gene 16 (SNHG16) (Entrez ID, 100507246) was initially identified as an oncogene in neuroblastoma. It is reported that the upregulation of SNHG16 expression is associated with the prognosis of patients with neuroblastoma (80). In thyroid papillary carcinoma, SNHG16 acts as a miR-497 'sponge', which targets and regulates the expression of BDNF and YAP1 and plays the role of an oncogene (81). In diffuse large B-cell lymphoma, SNHG16 interacts directly with miR-497 by acting as a ceRNA, which targets the expression of proto-oncogene serine/threonine-protein kinase, thereby promoting cell proliferation and inhibiting apoptosis (82).

The lncRNA HOXC13 antisense RNA (HOXC13-AS), located in 12q13.13, can accelerate the progression of tumors such as those of breast and nasopharyngeal cancer (83). A previous study has found that HOXC13-AS promotes the proliferation and growth of breast cancer cells in vitro and In vivo through the miR-497/phosphatase and tensin homolog axis (84).

The IncRNA LINC00473 is located on the 6q27 chromosome (85). In breast cancer, LINC00473 acts as a tumor promoter and accelerates tumor progression by competing for the expression of miR-497 (86). In esophageal squamous cell carcinoma, LINC00473 promotes cancer progression by regulating the miR-497/protein kinase AMP-activated catalytic subunit $\alpha 1$ axis (87).

The lncRNA metastasis-associated in lung adenocarcinoma transcript 1 (MALAT1) is an 8.5-kb lncRNA, located in $11 \mathrm{q} 13$. It was previously demonstrated that MALAT1 is widely expressed in normal tissues, suggesting that it plays a potentially important role in development and evolution (88). Experiments have shown that miR-497 suppresses the expression of MALAT1 after transcription, and MALAT1 also competes with miR-497 for its molecular target eukaryotic initiation factor 4E, to induce cell cycle arrest (53). In addition, MALAT1 directly binds to splicing factor proline- and glutamine-rich, indicating its multifaceted role in the pathophysiology of adrenocortical carcinoma (89).

The lncRNA DLX6 antisense RNA 1 (DLX6-AS1), located on human chromosome 7q21.3, was firstly identified to be highly expressed innormalbraintissues (90).Aprevious study hasfound that the DLX6-AS1/miR-497-5p/FZD4/FZD6/Wnt/ $\beta$-catenin signaling pathway is involved in the pathogenesis of pancreatic cancer (91).

The lncRNA LINC00339 is widely expressed in a variety of tissues and cells. It was recently reported that LINC00339 is overexpressed in pancreatic cancer cells and tissues, and that it increases the expression of IGF1-R by acting as an miR-497 'sponge', thereby promoting the proliferation, invasion and metastasis of cancer cells (92).

The IncRNA LINC01410, located on the 9q13 chromosome, may act as an oncogene in gastric cancer by promoting cell invasion and angiogenesis (93). It was recently reported that the expression of LINC01410 is increased in pancreatic cancer tissues and cells, while the downregulation of LINC01410 expression may inhibit the proliferation and migration of pancreatic cancer cells. The underlying mechanism may be closely associated with the regulation of the expression of miR-497 and the interferon inducible transmembrane protein 3 gene (94). 
The lncRNA AC009022.1 (PDXDC2P-NPIPB14P) is an important member of the IncRNA family, but its role in human tumors remains elusive. The study by Yu and Zhang (95) was the first to demonstrate that AC009022.1 enhances the proliferation and invasion of colorectal cancer cells by inhibiting the expression of miR-497 and promoting the expression of actin-related protein $3 \mathrm{~B}$.

The lncRNA CDKN2B antisense RNA 1 (CDKN2B-AS1) is located on human chromosome 9p21.3. It has been reported that the expression of this IncRNA is upregulated in tumor tissues and plays a carcinogenic role. A previous study has reported that CDKN2B-AS1 acts as an oncogene in the tumorigenesis of laryngeal squamous cell carcinoma by regulating the miR-497/cyclin-dependent kinase 6 axis (96).

All the IncRNAs associated with the regulation of miR-497 expression in cancer are shown in Table II.

Mutual regulation of miR-497 and circular RNAs (circRNAs). circRNAs are mainly produced from pre-mRNAs through variable splicing (97). Different from the traditional linear RNAs, which have (5' and $3^{\prime}$ ends), circRNAs have a closed-ring structure and, compared with miRNAs and lncRNAs, have a more stable structure and sequence conservation, with resistance to the digestion by RNase R (97). An increasing body of evidence indicates that circRNAs are involved in the regulation of tumorigenesis, including oncogenesis, differentiation and metastasis. At present, the research on circRNAs shows that their main function is to act as an 'miRNA sponge' (97).

circ 0018289 is located in chr10:46968580-46969453, has a length of $348 \mathrm{bp}$ and plays an important role in the proliferation, metastasis and invasion of cervical cancer cells. Through bioinformatics prediction and luciferase reporter gene detection, it was shown that circ_0018289 directly binds to miR-497 and plays an oncogenic role in cervical cancer (98).

circPVT1 originates from the PVT1 gene locus and is located in Chr8q24, but unlike lncPVT1, circPVT1 appears to be transcribed from its promoter. In addition, chromosome $8 \mathrm{q} 24$ carries the oncogene c-Myc (99). A previous study has reported that circPVT1 acts as an oncogene in head and neck squamous cell carcinoma and that the mut-p53/YAP/transcriptional enhanced associate domain complex regulates its expression in transcription (100). Further investigation revealed that circPVT1 causes targeted inhibition of miR-497, whereas miR-497 causes targeted regulation of mitotic checkpoint serine/threonine-protein kinase BUB1 (100). It was recently demonstrated that circPVT1 can directly bind to miR-497 and reduce the inhibitory effect of miR-497 on the expression of Bcl-2, thus inhibiting the apoptosis of NSCLC cells (101).

All the circRNAs associated with the regulation of miR-497 expression in cancer are shown in Table III.

Mutual regulation of miR-497 and TFs. In eukaryotes, TFs can specifically bind to a specific sequence upstream of the 5 end of the gene, thus affecting the transcription process from DNA to mRNA or miRNA. In this manner, TFs can regulate the expression of miRNAs positively or negatively.

The nuclear factor- $\kappa \mathrm{B}$ (NF- $\kappa \mathrm{B})$ signaling pathway was one of the first to be identified pathways associated with miRNA expression. It was more recently demonstrated that miR-497 directly targets the regulation of inhibitor $\kappa \mathrm{B}$ kinase $\beta$, which in turn affects the expression of NF- $\mathrm{KB}$ (102). Another study found that miR-497 is involved in the regulation of the NF- $\mathrm{KB} /$ matrix metallopeptidase (MMP)-9/prostate-specific antigen signaling pathway in prostate cancer (103). However, according to current research, the regulatory association between the NF-kB signaling pathway and miR-497 is different from those aforementioned. It was initially observed that activating NF- $\mathrm{KB}$ can increase the level of miR-497 (102). It was recently demonstrated that the inflammatory cytokine tumor necrosis-factor (TNF)- $\alpha$ inhibits the expression of miR-497 through negative transcriptional regulation mediated by NF- $\mathrm{KB}$, and that it upregulates the expression of spalt-like transcription factor 4 , and promotes the self-renewal and metastasis of HCC cells (104). The aforementioned evidence indicates that there is a negative feedback loop between miR-497 and the NF- $\kappa B$ signaling pathway that regulates its expression.

YAP1 is a key molecule of the Hippo signaling pathway and acts as a transcriptional coactivator. In NSCLC and HCC, miR-497 inhibits the proliferation of cancer cells by targeting YAP1 $(105,106)$. In papillary thyroid carcinoma, miR-497 inhibits cancer cell proliferation and invasion by negatively regulating the expression of YAP1 (107).

Slug is a type of TF that can promote the occurrence of EMT, and can increase the migration and invasion ability of tumor cells. A previous study found that the expression of miR-497 is significantly associated with EMT in breast cancer cells, which is mediated by the targeted regulation of Slug (108).

Hypoxia inducible factor-1 $\alpha$ (HIF-1 $\alpha)$ is a subunit of HIF-1. As a major transcriptional regulator, it can activate the transcription of $>40$ genes and participate in the inflammatory response (109). It was previously demonstrated that HIF-1 $\alpha$ binds to the site of hypoxia response element 1 in the $1.5-\mathrm{kb}$ region upstream of the miR-497 promoter, where it directly activates its transcription (110). It was observed that the expression of miR-497 decreased significantly under hypoxic conditions, whereas the expression of miR-497 increased after the cells were restored to a normoxic state for $24 \mathrm{~h}$. Therefore, it may be inferred that miR-497 is a hypoxia-induced miRNA. It was also been suggested that miR-497 inhibits angiogenesis in breast cancer by targeting HIF-1 $\alpha$ (111).

Twist is a highly conserved TF that plays an important role in embryonic development. The expression of Twist is involved in the occurrence, development, invasion and metastasis of breast cancer (112). Current research shows that Twist can promote angiogenesis in pancreatic cancer by targeting the miR-497/vascular endothelial growth factor A axis (113).

The SMAD family is composed of several TFs. SMAD3 is an important transporter in the transforming growth factor- $\beta$ (TGF- $\beta$ ) signal transduction pathway, and SMAD7 has been considered as an important negative feedback regulator of the TGF- $\beta$ signaling pathway in the past (114). It has been demonstrated that miR-497 directly interacts with the 3'-UTR sequence of SMAD3 transcripts, indicating that it may act as one of the regulators of the TGF- $\beta$ signaling pathway (115). In addition, it has been shown that miR-497 regulates the proliferation and invasion of breast cancer cells by targeting 
Table II. IncRNAs associated with the regulation of miR-497 expression in cancer.

\begin{tabular}{|c|c|c|c|c|c|c|}
\hline Cancer type & lncRNA & Expression & Targets & $\begin{array}{l}\text { Type of } \\
\text { interaction }\end{array}$ & Biological functions & (Refs.) \\
\hline \multirow[t]{5}{*}{ Gastric cancer } & XIST & Upregulated & miR-497, MACC1 & Neg & Promotes cell cycle progression & (64) \\
\hline & GACAT-3 & Upregulated & $\operatorname{miR}-497$ & Neg & Promotes cancer progression & $(68)$ \\
\hline & LINC-00662 & Upregulated & miR-497, YAP1 & Neg & Promotes cell proliferation & (74) \\
\hline & LINC-00978 & Upregulated & miR-497, NTRK3 & $\mathrm{Neg}$ & $\begin{array}{l}\text { Promotes cell proliferation and } \\
\text { tumorigenesis }\end{array}$ & (76) \\
\hline & NEAT1 & Upregulated & miR-497, PIK3R1 & Neg & Promotes cell proliferation & $(70)$ \\
\hline Osteosarcoma & PVT1 & Upregulated & miR-497, HK2 & Neg & $\begin{array}{l}\text { Promotes glucose metabolism, } \\
\text { cell proliferation }\end{array}$ & (66) \\
\hline \multirow{2}{*}{$\begin{array}{l}\text { Non-small cell } \\
\text { lung cancer }\end{array}$} & PVT1 & Upregulated & $\operatorname{miR}-497$ & Neg & Promotes tumorigenesis & $(67)$ \\
\hline & SNHG1 & Upregulated & miR-497, IGF1-R & Neg & Promotes cancer progression & $(78)$ \\
\hline \multirow[t]{3}{*}{ Breast cancer } & GACAT-3 & Upregulated & miR-497, CCND2 & Neg & Promotes cell proliferation & (69) \\
\hline & HOXC13-AS & Upregulated & miR-497, PTEN & Neg & Promotes cell proliferation & $(84)$ \\
\hline & LINC-00473 & Upregulated & $\operatorname{miR}-497$ & Neg & Acts as a tumor promoter & $(86)$ \\
\hline \multirow[t]{2}{*}{$\begin{array}{l}\text { Thyroid } \\
\text { carcinoma }\end{array}$} & LINC-00152 & Upregulated & miR-497, BDNF & Neg & $\begin{array}{l}\text { Promotes cell proliferation } \\
\text { and invasion }\end{array}$ & $(71)$ \\
\hline & SNHG16 & Upregulated & $\operatorname{miR}-497$ & Neg & Drives proliferation and invasion & $(81)$ \\
\hline Multiple myeloma & LINC-00152 & Upregulated & $\operatorname{miR}-497$ & Neg & Promotes cancer progression & $(72)$ \\
\hline $\begin{array}{l}\text { Adrenocortical } \\
\text { carcinoma }\end{array}$ & MALAT-1 & Upregulated & miR-497 & $\begin{array}{l}\text { Feedback } \\
\text { axis }\end{array}$ & Promotes tumorigenesis & $(89)$ \\
\hline \multirow[t]{3}{*}{ Pancreatic cancer } & DLX6-AS1 & Upregulated & $\begin{array}{l}\text { miR-497, FZD4, } \\
\text { FZD6, Wnt, } \\
\beta \text {-catenin }\end{array}$ & Neg & Promotes tumorigenesis & $(91)$ \\
\hline & LINC-00339 & Upregulated & miR-497, IGF1-R & Neg & $\begin{array}{l}\text { Promotes cell proliferation and } \\
\text { metastasis }\end{array}$ & $(92)$ \\
\hline & LINC-01410 & Upregulated & miR-497, IFITM3 & Neg & $\begin{array}{l}\text { Promotes cell proliferation and } \\
\text { metastasis }\end{array}$ & (94) \\
\hline \multirow[t]{2}{*}{ Colorectal cancer } & SNHG1 & Upregulated & $\operatorname{miR}-497$ & Neg & Promotes EMT & (79) \\
\hline & AC-009022.1 & Upregulated & $\begin{array}{l}\operatorname{miR}-497 \\
\text { ACTR3B }\end{array}$ & Neg & $\begin{array}{l}\text { Promotes cell proliferation, } \\
\text { migration and invasion }\end{array}$ & $(95)$ \\
\hline $\begin{array}{l}\text { Hepatocellular } \\
\text { carcinoma }\end{array}$ & XIST & Downregulated & $\begin{array}{l}\operatorname{miR}-497 \\
\text { PDCD4 }\end{array}$ & Neg & $\begin{array}{l}\text { Participates in cancer } \\
\text { development }\end{array}$ & $(55)$ \\
\hline $\begin{array}{l}\text { Diffuse large } \\
\text { B-cell lymphoma }\end{array}$ & SNHG16 & Upregulated & miR-497, PIM1 & Neg & $\begin{array}{l}\text { Promotes cell proliferation and } \\
\text { inhibits apoptosis }\end{array}$ & $(82)$ \\
\hline $\begin{array}{l}\text { Esophageal } \\
\text { squamous cell } \\
\text { carcinoma }\end{array}$ & LINC-00473 & Upregulated & $\begin{array}{l}\text { miR-497, } \\
\text { PRKAA1 }\end{array}$ & Neg & $\begin{array}{l}\text { Promotes cell proliferation and } \\
\text { metastasis }\end{array}$ & $(87)$ \\
\hline $\begin{array}{l}\text { Laryngeal } \\
\text { squamous cell } \\
\text { cancer }\end{array}$ & CDKN2B-AS1 & Upregulated & miR-497, CDK6 & Neg & $\begin{array}{l}\text { Promotes cell proliferation and } \\
\text { metastasis }\end{array}$ & $(96)$ \\
\hline
\end{tabular}

Neg, negative; lncRNA, long non-coding RNA; miR, miRNA.

SMAD7 (116). Another study demonstrated that miR-497 can enhance the invasiveness of oral squamous cell carcinoma cells by inhibiting SMAD7 (117).

Paired box (PAX) proteins are named after the highly conserved pairing box gene binding region in their structure. PAX2 is located on human chromosome 10 q25 and is highly expressed in ovarian cancer (118). It was recently reported that overexpression of miR-497 inhibits proliferation and induces the apoptosis of ovarian cancer cells by targeting PAX2 (119).

E2F transcription factor $3(\mathrm{E} 2 \mathrm{~F} 3)$ is a key regulator of the $G_{1} / S$ phase transition and plays an important role in the regulation of the cell cycle. A recent study demonstrated that miR-497 targeting inhibits the expression of E2F3 in vitro and, 
Table III. circRNAs associated with the regulation of miR-497 expression in cancer.

\begin{tabular}{|c|c|c|c|c|c|c|}
\hline Cancer type & circRNA & Expression & Target & Type of interaction & Biological functions & (Refs.) \\
\hline Cervical cancer & circ-0018289 & Upregulated & $\operatorname{miR}-497$ & $\mathrm{Neg}$ & $\begin{array}{l}\text { Promotes } \\
\text { tumorigenesis }\end{array}$ & (98) \\
\hline $\begin{array}{l}\text { Head and neck } \\
\text { squamous cell } \\
\text { carcinoma }\end{array}$ & circPVT1 & Upregulated & $\operatorname{miR}-497$ & Unknown & Oncogenic role & $(100)$ \\
\hline $\begin{array}{l}\text { Non-small cell } \\
\text { lung cancer }\end{array}$ & circPVT1 & Upregulated & $\operatorname{miR}-497$ & $\mathrm{Neg}$ & Promotes tumorigenesis & $(101)$ \\
\hline
\end{tabular}

miR, microRNA; circRNA, circular mRNA.

thus, inhibits the proliferation and invasion of human bladder transitional cell carcinoma cells (120).

PBX homeobox 3 (PBX3) belongs to the family of human PBX TFs. It was previously demonstrated that PBX3 is targeted by multiple miRNAs, such as let-7c, miR-200b, miR-222 and miR-424, and is essential for liver tumor-initiating cells (121). In addition, miR-497 was found to play an anti-tumor role in human multiple myeloma by targeting PBX3 (122).

SRY-box transcription factor 5 (SOX5) is an important member of the SOX family. The gene is located at 12p12.1 and can directly bind to DNA or bind to other proteins to regulate gene expression (123). It has been shown that SOX5 is the direct target of miR-497-5p, indicating that the overexpression of miR-497 induces cell apoptosis by inhibiting the expression of the SOX5 gene, which in turn inhibits the proliferation, migration and invasion of NSCLC (124).

SALL4 is a TF that plays an important role in maintaining the self-renewal and pluripotency of embryonic stem cells (104). It has been demonstrated that miR-497 acts as a tumor suppressor to inhibit the expression of SALL4 and regulate the metastasis of HCC cells (104). Further studies demonstrated that TNF- $\alpha$ activates the NF- $\kappa \mathrm{B}$ signaling pathway, causing p65 to enter the nucleus and bind to the p65 binding site on the miR-497 promoter, thereby inhibiting the transcription of miR-497, upregulating the expression of SALL4 and, ultimately, promoting the proliferation of HCC cells (104).

Estrogen receptor $\alpha(\mathrm{ER} \alpha)$ acts as a TF in the nucleus by regulating the transcription of downstream target genes. It was recently demonstrated that, in ER $\alpha$-negative breast cancer, the low levels of ER $\alpha$ reduce the expression of miR-497, thus promoting the expression of estrogen-related receptor $\alpha$, and enhancing the proliferation, migration and invasion of breast cancer cells by increasing macrophage migration inhibitory factor expression and MMP-9 activity (125).

All the TFs associated with the regulation of miR-497 expression in cancer are shown in Table IV. A map of the lncRNA-circRNA-TF-miR-497 regulatory network is shown in Fig. 1.

\section{Clinical significance of miR-497}

miR-497 in the diagnosis of tumors. Ideal biomarkers must be highly sensitive, specific and easy to obtain, so that they can be detected in easily accessible samples such as blood, saliva or urine. Previous studies have demonstrated that miRNAs in the serum or plasma may be used as non-invasive biomarkers for cancer diagnosis $(126,127)$. Animal experiments have demonstrated that the expression of miR-497 in tissues and in the circulation is positively correlated, indicating that the expression of miRNAs in the circulation may reflect their expression in tumor tissues (126). Similar results were obtained from a series of clinical studies. In patients with gliomas, the researchers found that miR-497 has diagnostic significance in preoperative grading, and can distinguish pleomorphic glioblastomas from low-grade gliomas, with high sensitivity and specificity (127). It was also reported that the downregulation of miR-497 expression in cancer tissue and plasma is consistent in nasopharyngeal carcinoma, indicating that plasma miR-497 may be used in the diagnosis of this disease (128). In addition, with the development of bioinformatics technology, an increasing number of biomarkers for disease diagnosis and staging have been identified. In patients with malignant astrocytoma, the concentration of 7 types of miRNAs (including miR-497) in the serum was found to be significantly decreased, and the comprehensive expression analysis of the 7-miRNA panel revealed that it had high sensitivity $(88.00 \%)$ and high specificity (97.87\%) in predicting malignant astrocytoma (16). In a study on the plasma miRNA profile of patients with bladder cancer, it was found that the expression of miR-497 in the plasma was significantly decreased, and the serum/plasma miR-497 exhibited relatively high sensitivity and specificity in the diagnosis of bladder cancer (129). Zhang et al (130) identified a group of miRNA markers, including miR-497, in the serum, which can distinguish patients with cervical cancer from those with cervical intraepithelial neoplasia and healthy subjects, with a high sensitivity and specificity, and may thus be recommended for the early non-invasive detection of cervical cancer. Furthermore, receiver-operating characteristic curve analysis demonstrated that serum miR-497 could distinguish colorectal cancer or precancerous lesions from normal controls with high sensitivity (80.91\%) and specificity (81.43\%), while univariate and multivariate analysis identified serum miR-497 as an independent prognostic factor for CRC (131).

miR-497 affects drug sensitivity and resistance. One of the most important reasons for the poor prognosis of postoperative radiotherapy and chemotherapy is drug resistance, which 
Table IV. Transcription factors associated with the regulation of miR-497 expression in cancer.

\begin{tabular}{|c|c|c|c|c|}
\hline Name & Target & Type of interaction & Cancer type & (Refs.) \\
\hline $\operatorname{miR}-497$ & YAP1 & Direct, neg & $\begin{array}{l}\text { Non-small cell lung cancer, hepatocellular carcinoma, } \\
\text { thyroid carcinoma }\end{array}$ & $(105-107)$ \\
\hline miR-497 & NF- $\kappa B(I K K \beta)$ & Direct, neg & Prostate cancer & $(102,103)$ \\
\hline miR-497 & Slug & Direct, neg & Breast carcinoma & (108) \\
\hline miR-497 & HIF-1 $1 \alpha$ & Indirect, neg & Breast carcinoma, & (111) \\
\hline miR-497 & SMAD3 & Direct, neg & Unknown & $(115)$ \\
\hline $\operatorname{miR}-497$ & SMAD7 & Direct, neg & Breast carcinoma, oral squamous cell carcinoma & $(116,117)$ \\
\hline miR-497 & E2F3 & Direct, neg & Bladder transitional cell carcinoma & (120) \\
\hline miR-497 & PAX2 & Direct, neg & Ovarian cancer & (119) \\
\hline miR-497 & PBX3 & Direct, neg & Multiple myeloma & $(122)$ \\
\hline miR-497 & SOX5 & Direct, neg & Non-small cell lung cancer & (124) \\
\hline miR-497 & Twist & Direct, neg & Pancreatic cancer & (113) \\
\hline miR-497 & SALL4 & Direct, neg & Hepatocellular carcinoma & (104) \\
\hline $\mathrm{NF}-\kappa \mathrm{B}$ & miR-497 & Indirect, neg & Hepatocellular carcinoma & (104) \\
\hline $\mathrm{ER} \alpha$ & miR-497 & Direct, neg & Breast carcinoma & (125) \\
\hline
\end{tabular}

Neg, negative; miR, microRNA.

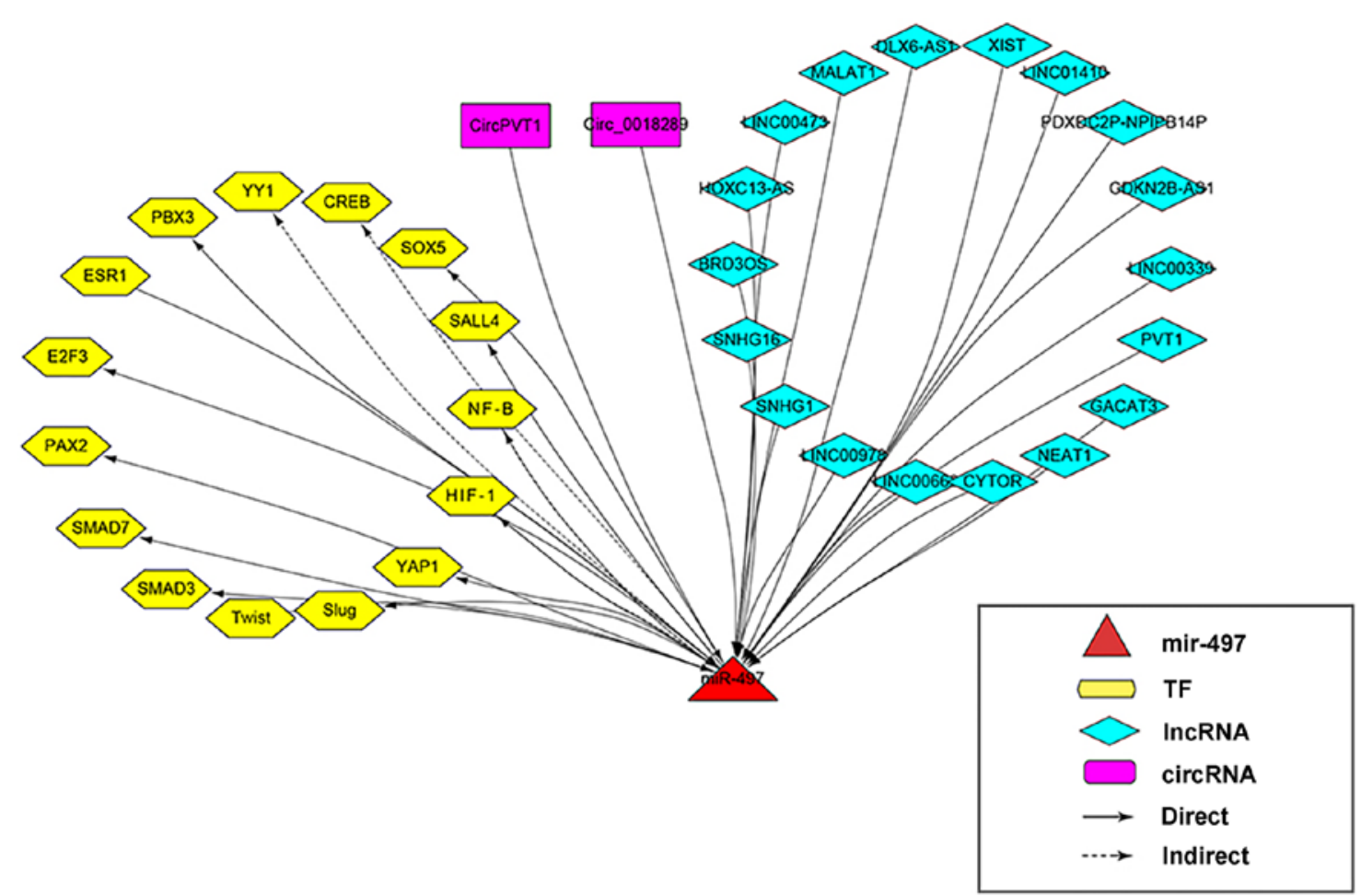

Figure 1. IncRNA-circRNA-TF-miR-497 regulatory network. lncRNA, long non-coding RNA; circRNA, circular RNA; TF, transcription factor; miR, miRNA; Direct, direct targeting; Indirect, indirect targeting.

adversely affects the survival time of the patients; therefore, it is particularly important to explore whether miR-497 can improve drug resistance. In osteosarcoma, miR-497 enhances the sensitivity of osteosarcoma cells to cisplatin through the phosphoinositide 3-kinase/Akt pathway (132). In ovarian cancer, miR-497 reduces cisplatin resistance of ovarian cancer cells by targeting mammalian target of rapamycin/P70S6K1 (133).
In addition, miR-497 exhibits similar results when studying drug resistance to other common chemotherapeutic drugs. In pancreatic ductal adenocarcinoma, miR-497 can increase the sensitivity of pancreatic ductal adenocarcinoma cells to erlotinib and gemcitabine (134). In lymphoma, the upregulation of miR-497 expression can enhance the chemosensitivity of lymphoma cells and significantly increase the survival rate of 
the patients (135). In multiple myeloma, miR-497 can increase the sensitivity of multiple myeloma cells to bortezomib (136). In colorectal cancer, miR-497 can enhance the sensitivity of colorectal cancer cells to oxaliplatin (137). Notably, although the majority of the studies have demonstrated that miR-497 agonists can increase the sensitivity of cancer cells to chemotherapeutic drugs (132-137), some studies have yielded different results $(138,139)$. A previous study have shown that miR-497 is involved in the resistance of NSCLC cells to gefitinib through the insulin-like growth factor-1 receptor bypass pathway (138). Temozolomide (TMZ) is mainly used in the treatment of gliomas. It has been demonstrated that overexpression of miR-497 reduces the sensitivity of glioma cells to TMZ chemotherapy (110). Further research has found that the downregulation of $\mathrm{miR}-497$ expression could enhance the cytotoxic effect of TMZ on glioma cells, suggesting that TMZ combined with miR-497 antagonists may help reduce the incidence of $\mathrm{TMZ}$ resistance in gliomas and increase the overall response rate of chemotherapy (139).

miR-497 reflects cancer prognosis. miR-497 plays an important role in the treatment of drug-resistant cancer and significantly affects the prognosis of the patients. Therefore, miR-497 may be a potential biomarker affecting the prognosis of cancer patients. It was previously observed that low expression of serum miR-497 is associated with a poor prognosis in patients with osteosarcoma (140). Subsequently, it was demonstrated that the expression level of miR-497 increases significantly following surgical resection of the primary tumor, indicating that serum miR-497 may be used to evaluate the effect of the surgery, and even as a prognostic index of malignant astrocytoma (16). It was recently reported that miR-497 in extracellular microvesicles is a predictive biomarker of the benefits of mitogen-activated protein kinase pathway inhibitor therapy in patients with metastatic cutaneous malignant melanoma (141). In addition to the aforementioned prognostic indicators, survival analysis may also be used to reflect the prognosis of disease treatment. Through Cox regression analysis, it was revealed that the downregulation of miR497 expression was associated with longer survival time in patients with pancreaticobiliary adenocarcinoma (142). miRNA-seq data analysis of The Cancer Genome Atlas revealed that miR-497 was negatively correlated with the survival of patients with oropharyngeal squamous cell carcinoma, which was verified in an independent cohort study (143). To further verify the potential predictive value of miR-497 expression level for prognosis, two meta-analyses of multiple studies were conducted. In 2018, a meta-analysis of 12 studies (including a total of 989 cancer patients) revealed that tumor patients with a high level of miR-497 expression exhibited longer OS times (144). In 2019, a meta-analysis of 15 studies (including a total of 1,760 participants) revealed that lower miR-497 expression levels were significantly correlated with shorter OS time, but not disease-free survival or relapse-free survival, indicating that miR-497 was not significantly correlated with early prediction, but may be of value as a biomarker of long-term prognosis (145).

\section{Conclusions and prospects}

The aim of the present review was to summarize the role of DNA copy number and epigenetics (DNA methylation,
IncRNAs, circRNAs and TFs) in the regulation of miR-497 expression. At the DNA level, the copy number of DNA is positively correlated with the expression of miR-497, and DNA methylation is one of the mechanisms underlying the abnormal expression of miR-497 in cancer. At the transcriptional level, lncRNAs and circRNAs act as miRNA sponges and inhibit miR-497 expression. In addition, the expression of miR-497 can not only be regulated by TFs, but can also be targeted to regulate the expression of TFs, in which there is even a feedback loop between miR-497 and certain TFs (e.g., NF- $\kappa \mathrm{B}$ and HIF-1 $\alpha$ ). Furthermore, the present review also summarized the potential of serum/plasma miR-497 as a non-invasive diagnostic marker, as a factor improving chemotherapeutic drug resistance and as a prognostic marker. Although the regulatory mechanisms of miR-497 expression in cancer were preliminarily summarized, the complex networks involved in the regulation of this expression are still incompletely understood. Moreover, due to the complexity of miRNA biosynthesis and the diversity of the target genes involved, it is necessary to further elucidate the role of miR-497 in tumors. The guidelines for diagnosis and treatment of primary liver cancer in China (2019 edition) points out that the current liver cancer detection kit based on a circulating miRNA model has been verified by multicenter clinical trials (in a cohort with 1,812 patients), has been registered with three types of medical devices by the State Drug Administration and has been put into clinical application (146). Although serum/plasma miR-497 may be used as a biomarker for diagnosis, it has not been verified in a large number of samples. Notably, most studies have demonstrated that miR-497 agonists can increase the sensitivity of cancer cells to chemotherapeutic drugs, and some studies have reported that the combination with miR-497 antagonists may help reduce the incidence of TMZ resistance in gliomas; thus, different drugs must to be used according to the different types of cancer. In addition, novel drugs for miR-497 must be developed. Understanding the regulatory mechanism of miR-497 expression will provide new approaches to further study the function of miR-497 and develop new drugs. In conclusion, the varying levels of miR-497 expression among different cancers and healthy patients plays an important role in the diagnosis, treatment and prognosis of several tumors, and it is worthwhile to study the main mechanism underlying this imbalance, as it may prove to be of value in the clinical setting.

\section{Acknowledgements}

Not applicable.

\section{Funding}

The present study was supported by grants from the Natural Science Foundation of China (grant no. 81641110) and the Guangdong Province Natural Science Foundation (grant no. 2015A030313725).

\section{Availability of data and materials}

Not applicable. 


\section{Authors' contributions}

GL analyzed the data and wrote the manuscript. ZX, SL and HL collected the data. KH and GX were involved in the conception and design of the study and revised the manuscript. All authors have read and approved the final version of the manuscript.

\section{Ethics approval and consent to participate}

Not applicable.

\section{Patient consent for publication}

Not applicable.

\section{Competing interests}

All the authors declare that they have no competing interests.

\section{References}

1. Bray F, Ferlay J, Soerjomataram I, Siegel RL, Torre LA and Jemal A: Global cancer statistics 2018: GLOBOCAN estimates of incidence and mortality worldwide for 36 cancers in 185 countries. CA Cancer J Clin 68: 394-424, 2018.

2. Shenouda SK and Alahari SK: MicroRNA function in cancer: Oncogene or a tumor suppressor? Cancer Metastasis Rev 28 : 369-378, 2009

3. Lee RC, Feinbaum RL and Ambros V: The C.elegans heterochronic gene lin-4 encodes small RNAs with antisense complementarity to lin-14. Cell 75: 843-854, 1993.

4. Fire A, Xu S, Montgomery MK, Kostas SA, Driver SE and Mello CC: Potent and specific genetic interference by double-stranded RNA in Caenorhabditis elegans. Nature 391: 806-811, 1998

5. Kozomara A, Birgaoanu M and Griffiths-Jones S: miRBase: From microRNA sequences to function. Nucleic Acids Res 47: D155-D162, 2019.

6. Joyce BT, Zheng Y, Zhang Z, Liu L, Kocherginsky M, Murphy R, Achenbach CJ, Musa J, Wehbe F, Just A, et al: miRNA-processing gene methylation and cancer risk. Cancer Epidemiol Biomarkers Prev 27: 550-557, 2018

7. Yang G, Xiong G, Cao Z, Zheng S, You L, Zhang T and Zhao Y: miR-497 expression, function and clinical application in cancer. Oncotarget 7: 55900-55911, 2016.

8. Menigatti M, Staiano T, Manser CN, Bauerfeind $\mathrm{P}$, Komljenovic A, Robinson M, Jiricny J, Buffoli F and Marra G: Epigenetic silencing of monoallelically methylated miRNA loci in precancerous colorectal lesions. Oncogenesis 2: e56, 2013.

9. Itesako T, Seki N, Yoshino H, Chiyomaru T, Yamasaki T, Hidaka H, Yonezawa T, Nohata N, Kinoshita T, Nakagawa M and Enokida $\mathrm{H}$ : The microRNA expression signature of bladder cancer by deep sequencing: The functional significance of the miR-195/497 cluster. PLoS One 9: e84311, 2014.

10. Wang W, Danaher RJ, Miller CS, Berger JR, Nubia VG, Wilfred BS, Neltner JH, Norris CM and Nelson PT: Expression of miR-15/107 family microRNAs in human tissues and cultured rat brain cells. Genomics Proteomics Bioinformatics 12: 19-30, 2014.

11. Yan L, Huang X, Shao Q, Huang M, Deng L, Wu Q, Zeng Y and Shao J: MicroRNA miR-21 overexpression in human breast cancer is associated with advanced clinical stage, lymph node metastasis and patient poor prognosis. RNA 14: 2348-2360, 2008

12. Guo J, Miao Y, Xiao B, Huan R, Jiang Z, Meng D and Wang Y Differential expression of microRNA species in human gastric cancer versus non-tumorous tissues. J Gastroen Hepatol 24: 652-657, 2009

13. Flavin RJ, Smyth PC, Laios A, O'Toole SA, Barrett C, Finn SP Russell S, Ring M, Denning KM, Li J, et al: Potentially important microRNA cluster on chromosome $17 \mathrm{p} 13.1$ in primary peritoneal carcinoma. Mod Pathol 22: 197-205, 2009.
14. Özata DM, Caramuta S, Velázquez-Fernández D, Akçakaya P, Xie H, Höög A, Zedenius J, Bäckdahl M, Larsson C and Lui W: The role of microRNA deregulation in the pathogenesis of adrenocortical carcinoma. Endocr-Relat Cancer 18: 643-655, 2011.

15. Caramuta S, Lee L, Ozata DM, Akçakaya P, Xie H, Höög A, Zedenius J, Bäckdahl M, Larsson C and Lui WO: Clinical and functional impact of TARBP2 over-expression in adrenocortical carcinoma. Endocr Relat Cancer 20: 551-564, 2013.

16. Yang C, Wang C, Chen X, Chen S, Zhang Y, Zhi F, Wang J, Li L, Zhou X, Li N, et al: Identification of seven serum microRNAs from a genome-wide serum microRNA expression profile as potential noninvasive biomarkers for malignant astrocytomas. Int J Cancer 132: 116-127, 2013.

17. Guo ST, Jiang CC, Wang GP, Li YP, Wang CY, Guo XY, Yang RH, Feng Y, Wang FH, Tseng HY, et al: MicroRNA-497 targets insulin-like growth factor 1 receptor and has a tumour suppressive role in human colorectal cancer. Oncogene 32: 1910-1920, 2013.

18. Wang L, Jiang CF, Li DM, Ge X, Shi ZM, Li CY, Liu X, Yin Y, Zhen L, Liu LZ and Jiang BH: MicroRNA-497 inhibits tumor growth and increases chemosensitivity to 5-fluorouracil treatment by targeting KSR1. Oncotarget 7: 2660-2671, 2016.

19. Zhang N, Shen Q and Zhang P: miR-497 suppresses epithelial-mesenchymal transition and metastasis in colorectal cancer cells by targeting fos-related antigen-1. Onco Targets Ther 9: 6597-6604, 2016.

20. Xu Y, Chen J, Gao C, Zhu D, Xu X, Wu C and Jiang J: MicroRNA-497 inhibits tumor growth through targeting insulin receptor substrate 1 in colorectal cancer. Oncol Lett 14: 6379-6386, 2017.

21. Hong S, Yan Z, Wang H, Ding L and Bi M: Up-regulation of microRNA-497-5p inhibits colorectal cancer cell proliferation and invasion via targeting PTPN3. Biosci Rep 39: BSR20191123, 2019.

22. Namløs HM, Meza-Zepeda LA, Barøy T, Østensen IHG, Kresse SH, Kuijjer ML, Serra M, Bürger H, Cleton-Jansen AM and Myklebost O: Modulation of the osteosarcoma expression phenotype by microRNAs. PLoS One 7: e48086, 2012.

23. Luo M, Shen D, Zhou X, Chen X and Wang W: MicroRNA-497 is a potential prognostic marker in human cervical cancer and functions as a tumor suppressor by targeting the insulin-like growth factor 1 receptor. Surgery 153: 836-847, 2013.

24. Xie Y, Wei RR, Huang GL, Zhang MY, Yuan YF and Wang HY: Checkpoint kinase 1 is negatively regulated by miR-497 in hepatocellular carcinoma. Med Oncol 31: 844, 2014.

25. He XX, Kuang SZ, Liao JZ, Xu CR, Chang Y, Wu YL, Gong J, Tian DA, Guo AY and Lin JS: The regulation of microRNA expression by DNA methylation in hepatocellular carcinoma. Mol Biosyst 11: 532-539, 2015.

26. Furuta M, Kozaki K, Tanimoto K, Tanaka S, Arii S, Shimamura T, Niida A, Miyano S and Inazawa J: The tumor-suppressive miR-497-195 cluster targets multiple cell-cycle regulators in hepatocellular carcinoma. PLoS One 8: e60155, 2013.

27. Yan JJ, Zhang YN, Liao JZ, Ke KP, Chang Y, Li PY, Wang M, Lin JS and He XX: miR-497 suppresses angiogenesis and metastasis of hepatocellular carcinoma by inhibiting VEGFA and AEG-1. Oncotarget 6: 29527-29542, 2015.

28. Ding Q, He K, Luo T, Deng Y, Wang H, Liu H, Zhang J, Chen K, Xiao J, Duan X, et al: SSRP1 contributes to the malignancy of hepatocellular carcinoma and is negatively regulated by miR-497. Mol Ther 24: 903-914, 2016.

29. Shen L, Li J, Xu L, Ma J, Li H, Xiao X, Zhao J and Fang L: miR-497 induces apoptosis of breast cancer cells by targeting Bcl-w. Exp Ther Med 3: 475-480, 2012.

30. Li D, Zhao Y, Liu C, Chen X, Qi Y, Jiang Y, Zou C, Zhang X, Liu S, Wang X, et al: Analysis of miR-195 and miR-497 expression, regulation and role in breast cancer. Clin Cancer Res 17: 1722-1730, 2011.

31. Wei C, Luo Q, Sun X, Li D, Song H, Li X, Song J, Hua K and Fang L: MicroRNA-497 induces cell apoptosis by negatively regulating $\mathrm{Bcl}-2$ protein expression at the posttranscriptional level in human breast cancer. Int J Clin Exp Pathol 8: 7729-7739, 2015.

32. Creevey L, Ryan J, Harvey H, Bray IM, Meehan M, Khan AR and Stallings RL: MicroRNA-497 increases apoptosis in MYCN amplified neuroblastoma cells by targeting the key cell cycle regulator WEE1. Mol Cancer 12: 23, 2013.

33. Zhao WY, Wang Y, An ZJ, Shi CG, Zhu GA, Wang B, Lu MY, Pan CK and Chen P: Downregulation of miR-497 promotes tumor growth and angiogenesis by targeting HDGF in non-small cell lung cancer. Biochem Biophys Res Commun 435: 466-471, 2013. 
34. Yin Q,Han Y,Zhu D, LiZ, Shan S, Jin W,Lu Q and Ren T: miR-145 and miR-497 suppress TGF- $\beta$-induced epithelial-mesenchymal transition of non-small cell lung cancer by targeting MTDH. Cancer Cell Int 18: 105, 2018.

35. Huang X, Wang L, Liu W and Li F: MicroRNA-497-5p inhibits proliferation and invasion of non-small cell lung cancer by regulating FGF2. Oncol Lett 17: 3425-3431, 2019.

36. Li W, Jin X, Deng X, Zhang G, Zhang B and Ma L: The putative tumor suppressor microRNA-497 modulates gastric cancer cell proliferation and invasion by repressing eIF4E. Biochem Biophys Res Commun 449: 235-240, 2014

37. Xie G, Ke Q, Ji YZ, Wang AQ, Jing M and Zou LL: FGFR1 is an independent prognostic factor and can be regulated by miR-497 in gastric cancer progression. Braz J Med Biol Res 52: e7816, 2018.

38. Feng L, Cheng K, Zang R, Wang Q and Wang J: miR-497-5p inhibits gastric cancer cell proliferation and growth through targeting PDK3. Biosci Rep 39: BSR20190654, 2019.

39. Wang W, Ren F, Wu Q, Jiang D, Li H, Peng Z, Wang J and Shi H: MicroRNA-497 inhibition of ovarian cancer cell migration and invasion through targeting of SMAD specific E3 ubiquitin protein ligase 1. Biochem Biophys Res Commun 449: 432-437, 2014.

40. Wang S, Mo Y, Midorikawa K, Zhang Z, Huang G, Ma N, Zhao W, Hiraku Y, Oikawa S and Murata M: The potent tumor suppressor miR-497 inhibits cancer phenotypes in nasopharyngeal carcinoma by targeting ANLN and HSPA4L. Oncotarget 6 : 35893-35907, 2015.

41. Ruan WD, Wang P, Feng S, Xue Y and Zhang B: MicroRNA-497 inhibits cell proliferation, migration, and invasion by targeting AMOT in human osteosarcoma cells. Onco Targets Ther 9: 303-313, 2016

42. Sun Z, Li A, Yu Z, Li X, Guo X and Chen R: MicroRNA-497-5p suppresses tumor cell growth of osteosarcoma by targeting ADP ribosylation factor-like protein 2. Cancer Biother Radiopharm 32: 371-378, 2017.

43. Chen Y, Kuang D, Zhao X, Chen D, Wang X, Yang Q, Wan J, Zhu Y, Wang Y, Zhang S, et al: miR-497-5p inhibits cell proliferation and invasion by targeting $\mathrm{KCa} 3.1$ in angiosarcoma. Oncotarget 7: 58148-58161, 2016

44. Yang H, Wu XL, Wu KH, Zhang R, Ju LL, Ji Y, Zhang YW, Xue SL, Zhang YX, Yang YF, et al: MicroRNA-497 regulates cisplatin chemosensitivity of cervical cancer by targeting transketolase. Am J Cancer Res 6: 2690-2699, 2016

45. Chen Y, Du J, Wang Y, Shi H, Jiang Q, Wang' Y, Zhang H, Wei Y, Xue W, Pu Z, et al: MicroRNA-497-5p induces cell cycle arrest of cervical cancer cells in s phase by targeting CBX4. Onco Targets Ther 12: 10535-10545, 2019.

46. Wang P, Meng X, Huang Y, Lv Z, Liu J, Wang G, Meng W, Xue S, Zhang Q, Zhang P, et al: MicroRNA-497 inhibits thyroid cancer tumor growth and invasion by suppressing BDNF. Oncotarget 8: 2825-2834, 2017.

47. Zhuang J, Ye Y, Wang G, Ni J, He S, Hu C, Xia W and Lv Z: MicroRNA-497 inhibits cellular proliferation, migration and invasion of papillary thyroid cancer by directly targeting AKT3. Mol Med Rep 16: 5815-5822, 2017.

48. Mizrahi A, Barzilai A, Gur-Wahnon D, Ben-Dov IZ, Glassberg S Meningher T, Elharar E, Masalha M, Jacob-Hirsch J, Tabibian-Keissar $\mathrm{H}$, et al: Alterations of microRNAs throughout the malignant evolution of cutaneous squamous cell carcinoma: The role of miR-497 in epithelial to mesenchymal transition of keratinocytes. Oncogene 37: 218-230, 2018.

49. Wei XH, Gu XL, Zhou XT, Ma M and Lou CX: miR-497 promotes the progression of cutaneous squamous cell carcinoma through FAM114A2. Eur Rev Med Pharmacol Sci 22: 7348-7355, 2018

50. Chai L, Kang XJ, Sun ZZ, Zeng MF, Yu SR, Ding Y, Liang JQ, Li TT and Zhao J: miR-497-5p, miR-195-5p and miR-455-3p function as tumor suppressors by targeting hTERT in melanoma A375 cells. Cancer Manag Res 10: 989-1003, 2018.

51. Lu F, Ye Y, Zhang H, He X, Sun X, Yao C, Mao H, He X, Qian C, Wang B, et al: miR-497/Wnt3a/c-jun feedback loop regulates growth and epithelial-to-mesenchymal transition phenotype in glioma cells. Int J Biol Macromol 120: 985-991, 2018.

52. Qu F, Ye J, Pan X, Wang J, Gan S, Chu C, Chu J, Zhang X, Liu M, $\mathrm{He} \mathrm{H}$ and Cui X: MicroRNA-497-5p down-regulation increases PD-L1 expression in clear cell renal cell carcinoma. J Drug Target 27: 67-74, 2019.

53. Hoareau-Aveilla C, Quelen C, Congras A, Caillet N, Labourdette D, Dozier C, Brousset P, Lamant L and Meggetto F: miR-497 suppresses cycle progression through an axis involving CDK6 in ALK-positive cells. Haematologica 104: 347-359, 2019.
54. Wang L, Li K, Lin X, Yao Z, Wang S, Xiong X, Ning Z, Wang J, $\mathrm{Xu} \mathrm{X}$, Jiang Y, et al: Metformin induces human esophageal carcinoma cell pyroptosis by targeting the miR-497/PELP1 axis. Cancer Lett 450: 22-31, 2019.

55. Zhang Y, Zhu Z, Huang S, Zhao Q, Huang C, Tang Y, Sun C, Zhang Z, Wang L, Chen $\mathrm{H}$, et al: lncRNA XIST regulates proliferation and migration of hepatocellular carcinoma cells by acting as miR-497-5p molecular sponge and targeting PDCD4. Cancer Cell Int 19: 198, 2019

56. Maura F, Cutrona G, Mosca L, Matis S, Lionetti M, Fabris S, Agnelli L, Colombo M, Massucco C, Ferracin M, et al: Association between gene and miRNA expression profiles and stereotyped subset \#4 B-cell receptor in chronic lymphocytic leukemia. Leuk Lymphoma 56: 3150-3158, 2015.

57. Wald AI, Hoskins EE, Wells SI, Ferris RL and Khan SA Alteration of microRNA profiles in squamous cell carcinoma of the head and neck cell lines by human papillomavirus. Head Neck 33: 504-512, 2011.

58. Matsuyama H and Suzuki HI: Systems and synthetic microRNA biology: From biogenesis to disease pathogenesis. Int J Mol Sci 21: 132, 2019 .

59. Daura-Oller E, Cabre M, Montero MA, Paternain JL and Romeu A: Specific gene hypomethylation and cancer: New insights into coding region feature trends. Bioinformation 3 : 340-343, 2009.

60. Esteller M: Relevance of DNA methylation in the management of cancer. Lancet Oncol 4: 351-358, 2003.

61. Zhang X, Wang W, Zhu W, Dong J, Cheng Y, Yin Z and Shen F: Mechanisms and functions of long non-coding RNAs at multiple regulatory levels. Int Mol Sci 20: 5573, 2019.

62. Loda A and Heard E: Xist RNA in action: Past, present, and future. PLoS Genet 15: e1008333, 2019.

63. Yang Z, Jiang $X$, Jiang $X$ and Zhao $H$ : X-inactive-specific transcript: A long noncoding RNA with complex roles in human cancers. Gene 679: 28-35, 2018

64. Ma L, Zhou Y, Luo X, Gao H, Deng X and Jiang Y: Long non-coding RNA XIST promotes cell growth and invasion through regulating miR-497/MACC1 axis in gastric cancer. Oncotarget 8: 4125-4135, 2017.

65. Li M, Tang X, Fu Y, Wang T and Zhu J: Regulatory mechanisms and clinical applications of the long non-coding RNA PVT1 in cancer treatment. Front Oncol 9: 787, 2019.

66. Song J, Wu X, Liu F, Li M, Sun Y, Wang Y, Wang C, Zhu K, Jia X, Wang B and Ma X: Long non-coding RNA PVT1 promotes glycolysis and tumor progression by regulating miR-497/HK2 axis in osteosarcoma. Biochem Biophys Res Commun 490: 217-2124, 2017

67. Guo D, Wang Y, Ren K and Han X: Knockdown of LncRNA PVT1 inhibits tumorigenesis in non-small-cell lung cancer by regulating miR-497 expression. Exp Cell Res 362: 172-179, 2018.

68. Feng L, Zhu Y, Zhang Y and Rao M: LncRNA GACAT3 promotes gastric cancer progression by negatively regulating miR-497 expression. Biomed Pharmacother 97: $136-142,2018$

69. Zhong H, Yang J, Zhang B, Wang X, Pei L, Zhang L, Lin Z, Wang Y and Wang C: LncRNA GACAT3 predicts poor prognosis and promotes cell proliferation in breast cancer through regulation of miR-497/CCND2. Cancer Biomark 22: 787-797, 2018.

70. Xia T, Chen J, Wu K, Zhang J and Yan Q: Long noncoding RNA NEAT1 promotes the growth of gastric cancer cells by regulating miR-497-5p/PIK3R1 axis. Eur Rev Med Pharmacol Sci 23: 6914-6926, 2019.

71. Sun Z, Guo X, Zang M, Wang P, Xue S and Chen G: Long non-coding RNA LINC00152 promotes cell growth and invasion of papillary thyroid carcinoma by regulating the miR-497/BDNF axis. J Cell Physiol 234: 1336-1345, 2019.

72. Yu T, Xu Z, Zhang X, Men L and Nie H: Long intergenic non-protein coding RNA 152 promotes multiple myeloma progression by negatively regulating microRNA-497. Oncol Rep 40: 3763-3771, 2018.

73. Xu D, Chen Y, Yuan C, Zhang S and Peng W: Long non-coding RNA LINC00662 promotes proliferation and migration in oral squamous cell carcinoma. Onco Targets Ther 12: 647-656, 2019.

74. Liu Z, Yao Y, Huang S, Li L, Jiang B, Guo H, Lei W, Xiong J and Deng J: LINC00662 promotes gastric cancer cell growth by modulating the Hippo-YAP1 pathway. Biochem Bioph Res Commun 505: 843-859, 2018 
75. Xu X, Gu J, Ding X, Ge G, Zang X, Ji R, Shao M, Mao Z, Zhang Y, Zhang J, et al: LINC00978 promotes the progression of hepatocellular carcinoma by regulating EZH2-mediated silencing of p21 and E-cadherin expression. Cell Death Dis 10: $752,2019$.

76. Bu J, Lv W, Liao Y, Xiao X and Lv B: Long non-coding RNA LINC00978 promotes cell proliferation and tumorigenesis via regulating microRNA-497/NTRK3 axis in gastric cancer. Int J Biol Macromol 123: 1106-1114, 2019.

77. Dong B, Chen X, Zhang Y, Zhu C and Dong Q: The prognostic value of lncRNA SNHG1 in cancer patients: A meta-analysis. BMC Cancer 19: 780, 2019.

78. Li Z, Lu Q, Zhu D, Han Y, Zhou X and Ren T: Lnc-SNHG1 may promote the progression of non-small cell lung cancer by acting as a sponge of miR-497. Biochem Bioph Res Commun 506: 632-640, 2018.

79. Bai J, Xu J, Zhao J and Zhang R: IncRNA SNHG1 cooperated with miR-497/miR-195-5p to modify epithelial-mesenchymal transition underlying colorectal cancer exacerbation. J Cell Physiol 235: 1453-1468, 2020.

80. Christensen LL, True K, Hamilton MP, Nielsen MM, Damas ND, Damgaard CK, Ongen H, Dermitzakis E, Bramsen JB Pedersen JS, et al: SNHG16 is regulated by the Wnt pathway in colorectal cancer and affects genes involved in lipid metabolism. Mol Oncol 10: 1266-1282, 2016.

81. Wen Q, Zhao L, Wang T, Lv N, Cheng X, Zhang G and Bai L: LncRNA SNHG16 drives proliferation and invasion of papillary thyroid cancer through modulation of miR-497. Onco Targets Ther 12: 699-708, 2019.

82.Zhu Q, Li Y, Guo Y, Hu L, Xiao Z, Liu X, Wang J, Xu Q and Tong X: Long non-coding RNA SNHG16 promotes proliferation and inhibits apoptosis of diffuse large B-cell lymphoma cells by targeting miR-497-5p/PIM1 axis. J Cell Mol Med 23: 7395-7405, 2019.

83. Liu N, Wang Z, Liu D and Xie P: HOXC13-AS-miR-122-5p-S ATB1-C-Myc feedback loop promotes migration, invasion and EMT process in glioma. Onco Targets Ther 12: 7165-7173, 2019

84.Li X, Wang Q, Rui Y, Zhang C, Wang W, Gu J, Tang J and Ding Y: HOXC13-AS promotes breast cancer cell growth through regulating miR-497-5p/PTEN axis. J Cell Physiol 234: 22343-22351, 2019 .

85. Zhang L, Wang Y, Li X, Xia X, Li N, He R, He H, Han C and Zhao W: ZBTB7A Enhances Osteosarcoma Chemoresistance by Transcriptionally Repressing IncRNALINC00473-IL24 Activity. Neoplasia 19: 908-918, 2017.

86. Bai J, Zhao W, Li W, Ying Z and Jiang D: Long noncoding RNA LINC00473 indicates a poor prognosis of breast cancer and accelerates tumor carcinogenesis by competing endogenous sponging miR-497. Eur Rev Med Pharmaco 23: 3410-3420, 2019.

87. He Z: LINC00473/miR-497-5p regulates esophageal squamous cell carcinoma progression through targeting PRKAA1. Cancer Biother Radiopharm 34: 650-659, 2019.

88. Li Z, Zhu Q, Zhang H, Hu Y, Wang G and Zhu Y: MALAT1: A potential biomarker in cancer. Cancer Manag Res 10: 6757-6768, 2018.

89. Hassan N, Zhao J, Glover A, Robinson BG and Sidhu SB: Reciprocal interplay of miR-497 and MALAT1 promotes tumourigenesis of adrenocortical cancer. Endocr Relat Cancer 26: 677-688, 2019.

90.Zhao P, Guan H, Dai Z, Ma Y, Zhao Y and Liu D: Long noncoding RNA DLX6-AS1 promotes breast cancer progression via miR-505-3p/RUNX2 axis. Eur J Pharmacol 865: 172778 , 2019

91. Yang J, Ye Z, Mei D, Gu H and Zhang J: Long noncoding RNA DLX6-AS1 promotes tumorigenesis by modulating miR-497-5p/FZD4/FZD6/Wnt/ $\beta$-catenin pathway in pancreatic cancer. Cancer Manag Res 11: 4209-4221, 2019.

92.Zhang R, Hao S, Yang L, Xie J, Chen S and Gu G: LINC00339 promotes cell proliferation and metastasis in pancreatic cancer via miR-497-5p/IGF1R axis. J BUON 24: 729-738, 2019.

93. Zhang J, Chen Z, Chen D, Tian X, Wang C, Zhou Z, Gao Y, Xu Y, Chen C, Zheng Z, et al: LINC01410-miR-532-NCF2-NF-kB feedback loop promotes gastric cancer angiogenesis and metastasis. Oncogene 37: 2660-2675, 2018.

94. Cai M, Xu L, Shen L and Zhang J: The expression of long non-coding RNA-LINC01410 in pancreatic cancer and its effect on proliferation and migration of pancreatic cancer cells Zhonghua Yi Xue Za Zhi 99: 1406-1411, 2019 (In Chinese).
95. Yu C and Zhang F: LncRNA AC009022.1 enhances colorectal cancer cells proliferation, migration, and invasion by promoting ACTR3B expression via suppressing miR-497-5p. J Cell Biochem 121: 1934-1944, 2020.

96. Cui X, Yu T, Shang J, Xiao D and Wang X: Long Non-Coding RNA CDKN2B-AS1 facilitates laryngeal squamous cell cancer through regulating miR-497/CDK6 Pathway. Onco Targets Ther 12: 8853-8862, 2019.

97. Yin Y, Long J, He Q, Li Y, Liao Y, He P and Zhu W: Emerging roles of circRNA in formation and progression of cancer. J Cancer 10: 5015-5021, 2019.

98. Gao Y, Zhang M, Xu B, Han L, Lan S, Chen J, Dong Y and Cao L: Circular RNA expression profiles reveal that hsa circ 0018289 is up-regulated in cervical cancer and promotes the tumorigenesis. Oncotarget 8: 86625-86633, 2017.

99. Adhikary J, Chakraborty S, Dalal S, Basu S, Dey A and Ghosh A: Circular PVT1: An oncogenic non-coding RNA with emerging clinical importance. J Clin Pathol 72: 513-519, 2019.

100. Verduci L,Ferraiuolo M, Sacconi A, Ganci F, Vitale J, Colombo T, Paci P, Strano S, Macino G, Rajewsky N and Blandino G: The oncogenic role of circPVT1 in head and neck squamous cell carcinoma is mediated through the mutant p53/YAP/TEAD transcription-competent complex. Genome Biol 18: 237, 2017.

101. Qin S, Zhao Y, Lim G, Lin H, Zhang X and Zhang X: Circular RNA PVT1 acts as a competing endogenous RNA for miR-497 in promoting non-small cell lung cancer progression. Biomed Pharmacother 111: 244-250, 2019.

102. Mechtler P, Singhal R, Kichina JV, Bard JE, Buck MJ and Kandel ES: MicroRNA analysis suggests an additional level of feedback regulation in the $\mathrm{NF}-\mathrm{KB}$ signaling cascade. Oncotarget 6: 17097-17106, 2015.

103. Kong X, Duan L, Qian X, Xu D, Liu H, Zhu Y and Qi J: Tumor-suppressive microRNA-497 targets IKK $\beta$ to regulate $\mathrm{NF}-\kappa \mathrm{B}$ signaling pathway in human prostate cancer cells. Am J Cancer Res 5: 1795-1804, 2015.

104. Zhao B, Wang Y, Tan X, Ke K, Zheng X, Wang F, Lan S, Liao N, Cai Z, Shi Y, et al: Inflammatory Micro-environment contributes to stemness properties and metastatic potential of HCC via the NF- $\kappa \mathrm{B} / \mathrm{miR}-497 / \mathrm{SALL} 4$ Axis. Mol Ther Oncolytics 15: 79-90, 2019.

105. Huang C, Ma R, Yue J, Li N, Li Z and Qi D: miR-497 Suppresses YAP1 and Inhibits Tumor Growth in Non-Small Cell Lung Cancer. Cell Physiol Biochem 37: 342-352, 2015.

106. Zhang L, Yu Z, Xian Y and Lin X: microRNA-497 inhibits cell proliferation and induces apoptosis by targeting YAP1 in human hepatocellular carcinoma. FEBS Open Bio 6: 155-164, 2016.

107. Cheng H, Dong H, Feng J, Tian H, Zhang H and Xu L: miR-497 inhibited proliferation, migration and invasion of thyroid papillary carcinoma cells by negatively regulating YAP1 expression. Onco Targets Ther 11: 4711-4721, 2018

108. Wu Z, Li X, Cai X, Huang C and Zheng M: miR-497 inhibits epithelial mesenchymal transition in breast carcinoma by targeting Slug. Tumour Biol 37: 7939-7950, 2016.

109. Lin D and Wu J: Hypoxia inducible factor in hepatocellular carcinoma: A therapeutic target. World J Gastroenterol 21: 12171-12178, 2015.

110. Lan J, Xue Y, Chen H, Zhao S, Wu Z, Fang J, Han C and Lou M: Hypoxia-induced miR-497 decreases glioma cell sensitivity to TMZ by inhibiting apoptosis. FEBS Lett 588: 3333-3339, 2014

111. Wu Z, Cai X, Huang C, Xu J and Liu A: miR-497 suppresses angiogenesis in breast carcinoma by targeting HIF-1 $\alpha$. Oncol Rep 35: 1696-1702, 2016.

112. Qiao W, Jia Z, Liu H, Liu Q, Zhang T, Guo W, Li P, Deng M and Li S: Prognostic and clinicopathological value of Twist expression in breast cancer: A meta-analysis. PLoS One 12: e186191, 2017

113. Liu A, Huang C, Cai X, Xu J andYang D: Twist promotes angiogenesis in pancreatic cancer by targeting miR-497/VEGFA axis. Oncotarget 7: 25801-25814, 2016.

114. Gu YY, Liu XS, Huang XR, Yu XQ and Lan HY: Diverse role of TGF- $\beta$ in kidney disease. Front Cell Dev Biol 8: 123, 2020.

115. Jafarzadeh M, Soltani BM, Dokanehiifard S, Kay M, Aghdami N and Hosseinkhani S: Experimental evidences for hsa-miR-497-5p as a negative regulator of SMAD3 gene expression. Gene 586: 216-221, 2016.

116. Liu J, Zhou Y, Shi Z, Hu Y, Meng T, Zhang X, Zhang S and Zhang J: microRNA-497 modulates breast cancer cell proliferation, invasion, and survival by targeting SMAD7. DNA Cell Biol 35: 521-529, 2016 
117. $\mathrm{Hu} \mathrm{J}, \mathrm{Xu} \mathrm{J}$ and Ge W: miR-497 enhances metastasis of oral squamous cell carcinoma through SMAD7 suppression. Am J Transl Res 8: 3023-3031, 2016.

118. Al-Hujaily EM, Tang Y, Yao DS, Carmona E, Garson K and Vanderhyden BC: Divergent roles of PAX2 in the etiology and progression of ovarian cancer. Cancer Prev Res (Phila) 8: 1163-1173, 2015.

119. Lin Z, Zhao J, Wang X, Zhu X and Gong L: Overexpression of microRNA-497 suppresses cell proliferation and induces apoptosis through targeting paired box 2 in human ovarian cancer. Oncol Rep 36: 2101-2107, 2016.

120.Zhang Y, Zhang Z, Li Z, Gong D, Zhan B, Man X and Kong C: MicroRNA-497 inhibits the proliferation, migration and invasion of human bladder transitional cell carcinoma cells by targeting E2F3. Oncol Rep 36: 1293-1300, 2016.

121. Han H, Du Y, Zhao W, Li S, Chen D, Zhang J, Liu J, Suo Z, Bian X, Xing B and Zhang Z: PBX3 is targeted by multiple miRNAs and is essential for liver tumour-initiating cells. Nat Commun 6: 8271, 2015.

122. Yu T, Zhang X, Zhang L, Wang Y, Pan H, Xu Z and Pang X: MicroRNA-497 suppresses cell proliferation and induces apoptosis through targeting PBX3 in human multiple myeloma. Am J Cancer Res 6: 2880-2889, 2016.

123. Ma S, Chan YP, Woolcock B, Hu L, Wong KY, Ling MT, Bainbridge T, Webber D, Chan TH, Guan XY, et al: DNA fingerprinting tags novel altered chromosomal regions and identifies the involvement of SOX5 in the progression of prostate cancer Int J Cancer 124: 2323-2332, 2009.

124.Li G, Wang K, Wang J, Qin S, Sun X and Ren H miR-497-5p inhibits tumor cell growth and invasion by targeting SOX5 in non-small-cell lung cancer. J Cell Biochem 120: 10587-10595, 2019.

125. Han L, Liu B, Jiang L, Liu J and Han S: MicroRNA-497 downregulation contributes to cell proliferation, migration, and invasion of estrogen receptor alpha negative breast cancer by targeting estrogen-related receptor alpha. Tumour Biol 37: 13205-13214, 2016.

126. Waters PS, McDermott AM, Wall D, Heneghan HM, Miller N, Newell J, Kerin MJ and Dwyer RM: Relationship between circulating and tissue microRNAs in a murine model of breast cancer. PLoS One 7: e50459, 2012.

127. Regazzo G, Terrenato I, Spagnuolo M, Carosi M, Cognetti G, Cicchillitti L, Sperati F, Villani V, Carapella C, Piaggio G, et al: A restricted signature of serum miRNAs distinguishes glioblastoma from lower grade gliomas. J Exp Clin Cancer Res 35: 124, 2016.

128. Murata M: Inflammation and cancer. Environ Health Prev Med 23: 50, 2018

129. Du M, Shi D, Yuan L, Li P, Chu H, Qin C, Yin C, Zhang Z and Wang M: Circulating miR-497 and miR-663b in plasma are potential novel biomarkers for bladder cancer. Sci Rep 5: 10437, 2015.

130. Zhang Y, Zhang D, Wang F, Xu D, Guo Y and Cui W: Serum miRNAs panel (miR-16-2*, miR-195, miR-2861, miR-497) as novel non-invasive biomarkers for detection of cervical cancer Sci Rep 5: 17942, 2015.

131. Zou G, Wang R and Wang M: Clinical response and prognostic significance of serum miR-497 expression in colorectal cancer. Cancer Biomark 25: 11-18, 2019.

132. Shao X, Miao M, Xue J, Xue J, Ji X and Zhu H: The Down-regulation of MicroRNA-497 contributes to cell growth and cisplatin resistance through PI3K/Akt pathway in osteosarcoma. Cell Physiol Biochem 36: 2051-2062, 2015.

133. Xu S, Fu G, Tao Z, OuYang J, Kong F, Jiang B, Wan X and Chen K: miR-497 decreases cisplatin resistance in ovarian cancer cells by targeting mTOR/P70S6K1. Oncotarget 6 : 26457-26471, 2015
134. Xu J, Wang T, Cao Z, Huang H, Li J, Liu W, Liu S, You L, Zhou L, Zhang T and Zhao Y: miR-497 downregulation contributes to the malignancy of pancreatic cancer and associates with a poor prognosis. Oncotarget 5: 6983-6993, 2014.

135. Troppan K, Wenzl K, Pichler M, Pursche B, Schwarzenbacher D, Feichtinger J, Thallinger GG, Beham-Schmid C, Neumeister P and Deutsch A: miR-199a and miR-497 are associated with better overall survival due to increased chemosensitivity in diffuse large B-cell lymphoma patients. Int J Mol Sci 16: $18077-18095,2015$.

136. Tian F, Zhan Y, Zhu W, Li J, Tang M, Chen X and Jiang J: MicroRNA-497 inhibits multiple myeloma growth and increases susceptibility to bortezomib by targeting Bcl-2. Int J Mol Med 43: 1058-1066, 2019.

137. Poel D, Boyd LNC, Beekhof R, Schelfhorst T, Pham TV, Piersma SR, Knol JC, Jimenez CR, Verheul HMW and Buffart TE: Proteomic analysis of miR-195 and miR-497 replacement reveals potential candidates that increase sensitivity to oxaliplatin in MSI/P53wt colorectal cancer cells. Cells 8: $1111,2019$.

138. Ma W, Kang Y, Ning L, Tan J, Wang H and Ying Y: Identification of microRNAs involved in gefitinib resistance of non-small-cell lung cancer through the insulin-like growth factor receptor 1 signaling pathway. Exp Ther Med 14: 2853-2862, 2017.

139. Zhu D, Tu M, Zeng B, Cai L, Zheng W, Su Z and Yu Z Up-regulation of miR-497 confers resistance to temozolomide in human glioma cells by targeting mTOR/Bcl-2. Cancer Med 6: 452-462, 2017

140. Pang P, Shi X, Huang W and Sun K: miR-497 as a potential serum biomarker for the diagnosis and prognosis of osteosarcoma. Eur Rev Med Pharmacol Sci 20: 3765-3769, 2016.

141. Svedman FC, Lohcharoenkal W, Bottai M, Brage SE, Sonkoly E, Hansson J, Pivarcsi A and Eriksson H: Extracellular microvesicle microRNAs as predictive biomarkers for targeted therapy in metastastic cutaneous malignant melanoma. PLoS One 13: e206942, 2018.

142. Sandhu V, Bowitz Lothe IM, Labori KJ, Lingjærde OC, Buanes T, Dalsgaard AM, Skrede ML, Hamfjord J, Haaland T, Eide TJ, et al: Molecular signatures of mRNAs and miRNAs as prognostic biomarkers in pancreatobiliary and intestinal types of periampullary adenocarcinomas. Mol Oncol 9: 758-771, 2015.

143. Wong N, Khwaja SS, Baker CM, Gay HA, Thorstad WL, Daly MD, Lewis JS Jr and Wang X: Prognostic microRNA signatures derived from The Cancer Genome Atlas for head and neck squamous cell carcinomas. Cancer Med 5: 1619-1628, 2016.

144. Feng J, Gu X, Liu L, Lu M, Ma X, Cao Y, Jiang R, Wang B and Zhao Q: Prognostic role of microRNA-497 in cancer patients: A Meta-analysis. J Cancer 9: 3334-3342, 2018

145. Liu Z, Wu S, Wang L, Kang S, Zhao B, He F, Liu X, Zeng Y and Liu J: Prognostic value of MicroRNA-497 in various cancers: A systematic review and Meta-analysis. Dis Markers 2019: 2491291, 2019

146. Department of Medical Administration, National Health and Health Commission of the People's Republic of China: Guidelines for diagnosis and treatment of primary liver cancer in China (2019 edition). Zhonghua Gan Zang Bing Za Zhi 28: 112-128, 2020 (In Chinese).

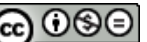

This work is licensed under a Creative Commons Attribution-NonCommercial-NoDerivatives 4.0 International (CC BY-NC-ND 4.0) License. 